\title{
Co-workers' impact on attitudinal behavior of the faculty members of educational institutions of Nepal
}

\author{
Amrit Kumar Sharma Gaire ${ }^{1}$ \& Prof. Dr. Fatta Bahadur KC ${ }^{2}$ \\ ${ }^{1} \mathrm{PhD}$ Scholar, Mewar University, Rajasthan, India \\ Email: sharmagaire@gmail.com \\ ${ }^{2}$ Tribhuvan University, Kathmandu, Nepal \\ Email: fattakc@hotmail.com \\ Corresponding Author \\ Amrit Kumar Sharma Gaire \\ Email: sharmagaire@gmail.com
}

\begin{abstract}
This paper attempts to analyze the relationship between co-workers' behavior and its impact on attitudinal behavior of the faculty members. The co-worker's behavior such as team support and lack of team support are used as an independent dimension and employee attitudinal behavior such as job satisfaction, job performance and job commitment are used as a dependent variable. The major objective of this research was to identify the effect on attitudinal behavior of faculty members' of higher educational institutions of Nepal due to their co-worker's behavior. Pair $t$ test was used to examine between the current and expectation co-worker's behavior of faculty members in the working place. Similarly, the one way analysis of variance was also used to test the hypothesis. The sample size was 400 faculty members. The findings show that here is significant relationship between the current and expected perception of the faculty towards the co-workers' behavior. Similarly, the findings of team support co-workers' behavior has positive significant and with lack of team support co-workers' behavior has negatively significant difference with attitudinal behavior of the faculty.
\end{abstract}

\section{KEYWORDS}

Co-worker's behavior, job commitment, job performance, and job satisfaction

\section{INTRODUCTION}

Co-workers are the colleagues working at the same hierarchical level who have no formal authority over one another in any organizations. The term co-worker refers to any individual with whom one works (including supervisors and subordinate employees). However, co-worker's relationships are often assumed to refer specifically among peer employees. Co-workers provide different valences of influence, positive (social support) and negative (antagonism) to their colleagues. Co-workers assist one another in their tasks when needed by sharing knowledge and expertise as well as providing encouragement and support. The co-operation and understanding between the peers tend to influence the positive level of job satisfaction, job commitment and job performance. Co-workers support is the source of positive spirit which leads employee towards the accomplishment of objectives. At the work place in team works, employees are like a family and work with a same wavelength and understand the problems and difficulties of one another in a better way than anybody else can, this in turn enhances their efficiency while they work. 


\section{Review of literature}

Co-workers are proximal to their colleagues, in immediate contact with them, and of equal status. Their influence on peers' work outcomes is significant, even then controlling for leader influences. As a result, the influence of one co-worker's behavior on performance of other coworkers' behavior may be stronger than the influence of the organization and the supervisor. Thus, the relation between the different aspects of co-workers' support in the working place is important because it influences for a variety of work outcomes (Chiaburu, 2010).

The nature and quality of peer relationships depend on the relation of individual as well as the organization. The findings of(Kinnaird, Dabbish, Kiesler, \& Faste, 2013)co-worker's transparency in a micro task market place taking different number of co-worker group showed a strong correlation between the larger numbers of co-workers group. Further they found the positive influence of the peer relation on motivation and work quality. Likewise, the findings of another study conducted amongst 1250 food brand employees found that positive relationship with co-workers enhances job satisfaction among the employees in the organization (Betra, 2005).

Group cohesiveness helps employee to better recognize interdependence between their own and co-workers' task. When cohesion exist within a work group it usually leads effectiveness within a group and makes the job more enjoyable (Morris, 2009). The social context of work is also likely to have a significant impact on a worker's attitude and behavior.

A study conducted by (Hasan \& Subhani, 2012) on the empirical investigation of co-worker's motivational efforts on morale and job commitments of employees found that various motivational efforts have a great impact on employee job commitment. Similarly, another study on effect of co-worker and student-teacher relationship on teacher's organizational commitment found that there is a close relationship between teachers and their colleague's job commitment (Wainaina, Kipchumba, \& Kombo, 2014). The previous research (Wainaina, Kipchumba, \& Kombo, 2014), revealed that the co-workers' behavior and teachers job commitment in Kenya was found correlated and indicated that school administrators and human resource management practitioners can enhance their employees' organizational commitment by creating conducive work environment.

The friendship between the co-workers support helps to increase the efficiency and create the embedment towards the organization. The qualitative study explored workplace friendships among a particular frontline employees, associates working in five star hotels and found that workplace friendships associate with job embedded. They also added that they have stayed at their jobs longer than anticipated due to the friendships they have made with other job members in the organization (Asgharian, Md.Yusoff, Yaser Mazhari, Mardani, \& Hazrat Soltan, 2013). Similarly, The empirical study on "Impact of teamwork on employee coordination: A case of Pakistan" found significant relationship of team support work and productivity. Further they added, in team support work not only the stress and pressure is being shared, but it also makes people able to work simultaneously to complete the individual task, which diminishes the time and increases the speed with which objectives are achieved (Rasool \& Lodhi, 2015).

Similarly, the study (Chou \& Robert, 2008) revealed that the co-worker's instrumental and emotional support helped to increase job satisfaction. Likewise, the regression analysis result 


\section{JOURNAL OF ADVANCED ACADEMIC RESEARCH (JAAR) J Jan 2016}

(Rizwan, et al., 2012) found that the team work in an organization helped to increase job satisfaction of the employee.

\section{Statement of problem}

The co-workers' behavior is very important in every organization. The co-worker's behavior especially between the peer play an important role in performing the jobs efficiently and effectively. Now, the trend to recognize the importance between the peers has increased. The coworker's effect on the attitudinal behavior of the faculty, which has not been studied deeply yet in Nepalese context especially in educational institutions. In a teamwork environment, the members lead and manage the things by themselves and hence they successfully accomplish the organizational tasks and targets. Taking into consideration the increasing amount of time individuals spend at work, the importance of context in teamwork research, and the scholarly call for a more comprehensive understanding of workplace relationships, exploration of teamwork at work presents a research agenda of both critical and timely importance.

\section{Thus, the study has the followings objectives:}

To find out the relationship between the current and expected co-worker's behavior of the faculty observed in their working place.

To examine the relationship between the co-worker's behavior and attitudinal behavior of faculty members

The following hypothesis has been formulated based on the given objectives.

H01: There is no significant difference between current and expected co-worker's behavior of faculty (employee) members in educational institutions of Nepal.

H02: There is no significant relationship between team support, co-worker's behavior and attitudinal behavior (job satisfaction, job commitment and job performance) of faculty members.

H03: There is no significant relationship between lack of co-worker's support and attitudinal behavior (job satisfaction, job commitment and job performance) of faculty members.

\section{Theoretical and conceptual frame work}

The study is based on the social exchange theory. This theory basically anchored in the concept that social conduct is the product of the process of exchange which is to maximize benefits and consequently minimize costs. This theory that has its roots from the works of (Homans, 1958; Balu, 1964) emphasizes that the exchange can only be understood through the material and nonmaterial goods (e.g. Symbols of approval or prestige). This theory suggests that individuals consider potential reward and the risks linked to social relationships.

This study attempts to analyze the relationship between the co-workers' behavior and their impact on attitudinal behavior of the faculty of educational institutions of Nepal. The co-workers' behavior has been categorized into team support co-workers' behavior and lack of team support co-workers' behavior. The team support co-workers' behavior has been taken as a positive determinant between the co-workers' and lack of team support co-workers' behavior has been taken as a negative determinant between the peers in the education institutions. Thus, in this 
study the relationship between two categories of co- workers' behavior and attitudinal behavior of faculty members have been analyzed. The theoretical framework has been given below.

Figure 1: theoretical framework model

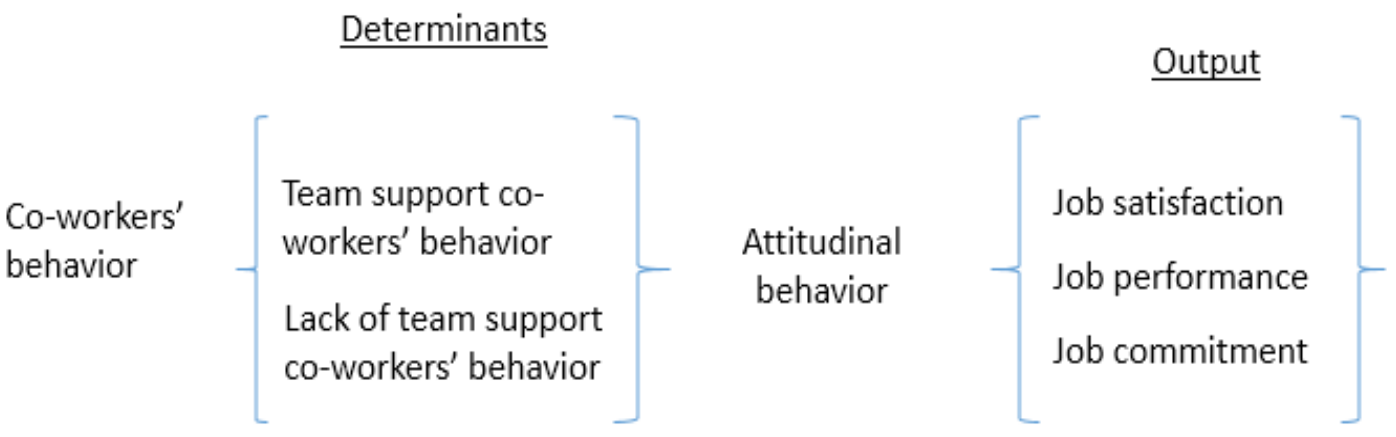

\section{METHOD}

The population of this study were the faculty members from constituent, community and private higher educational institutions under Tribuvan University located at Mid-western Development Region of Nepal. Three multi - stage sampling methods were used in selecting the sample of this study. Firstly, the Mid-western Development Region was selected out of five development regions. In second step, eleven campuses were selected from Mid-western Development Region considering the three ecological belt i.e. Hill, Mountain and Tarai area purposively. Then, in third step, the respondent from eleven campuses were randomly selected. In the course of data collection, the researcher visited the selected campuses personally and distributed questionnaires amongst faculty members and collected 400 respondent response at some pre-determined later date. Pair $\mathrm{t}$-teat and analysis of variance was used to test the hypothesis. In the course of data collection, the structured closed ended questionnaire was used based on Likert- type scale. The factor analysis was used to reduce the data. Cronbach's Alpha was used to measure the internal consistency and reliability of the instrument. The value calculated of Cronbach Alpha was .822 in this study.

\section{RESULT AND DISCUSSION}

\section{Demographic profile of participants}

The demographic information of respondent were collected based on gender, job status, campus status, education status, age of the faculty, working experience, income level etc. The participants of this study were the faculty members of eleven (Constituent, community and private) campuses located at Mid-western Development Region of Nepal affiliated to Tribhuvan University. Of the 400 participants 375 were males and 25 were females. The age range of participants was 25 to 61 years with mean age of 37.57 years. The position held by the participants were campus chief: 3 , assistant campus chief: 15 , head of the department: 24 and teaching faculties: 358. The educational statuses of the participants were $\mathrm{PhD} 18$, MPhil 4 and post graduate 378 . The job statuses of the participants were full timers: 246 and part timers were 154. The numbers of participants based on campus status were; constituent campus: 260, 
community campus: 94 and private campus: 46. The working experience of the participant was 1 year to 35 years with mean experience of 7.98 years.

\section{Co-workers' behavior}

The co-worker's behavior was measured using 12 questions in 5 point scales. The instrument assessed employees' perception expected from their peers' / co-workers' behavior in the working place. The participants indicated their feelings with peers / co-workers behavior on each item using 5 point scales anchored by 5 very high and 1 very low. Out of 12 questions 3 questions were reversed scales. The co-worker's behavior was measured between the current and expected behavior observed by the participants in their working places.

H01: There is no significant difference between current and expected co-worker's behavior of faculty members in educational institutions of Nepal.

Table 1:Pair t-test of current and expected co- worker's behavior

\begin{tabular}{|c|c|c|c|c|c|c|c|c|}
\hline \multirow{3}{*}{$\begin{array}{l}\text { Pair } \\
\text { CCB and ECB }\end{array}$} & \multicolumn{5}{|c|}{ Total Paired Difference } & \multirow[t]{3}{*}{$\mathrm{T}$} & \multirow[t]{3}{*}{$\mathrm{df}$} & \multirow{3}{*}{$\begin{array}{l}\text { Sig.(2- } \\
\text { taild) }\end{array}$} \\
\hline & \multirow[t]{2}{*}{ Mean } & \multirow{2}{*}{$\begin{array}{l}\text { Std. } \\
\text { dev. }\end{array}$} & \multirow{2}{*}{$\begin{array}{l}\text { Std. } \\
\text { Error }\end{array}$} & \multicolumn{2}{|c|}{$95 \%$ Con. level } & & & \\
\hline & & & & Lower & Upper & & & \\
\hline $\mathrm{CCB}-\mathrm{ECB}$ & -11.905 & 8.131 & 0.407 & -12.704 & -11.106 & -29.281 & 399 & .000 \\
\hline
\end{tabular}

CCB (current co-worker's behavior), ECB (expected co-worker's behavior), Source: survey data 2015

The difference of mean value presented in table 1, between the current and expected co-worker's behavior is found -11.905 . This indicates that the current mean value is lower than the expected mean value observed by the faculties. Similarly, the result of pair t- test presented in Table 1, the significant value of $\mathrm{p}$ is $<.05$ here. Hence, the null hypothesis is rejected at $5 \%$ level of significance and the conclusion is made that there is significant difference between the current and expected mean of co- worker's behavior observed by the faculties. It indicates that the increased support of co-workers' in a team, on the similar range will motivate the faculty which helps to lead the faculties' job satisfaction, job performance and job commitment and vice versa.

The empirical study of "impact of teamwork on employee motivation" a case study of banking sector of Pakistan among 200 participants found that there is a positive relationship between team work and employee motivation (Irfan \& Lodhi, 2015). Further they added those employees working in a team are more satisfied with their jobs and prove themselves as an asset of organization. The basic mission of team building is to ensure self-development, effective communication, leadership skills and the ability to inculcate team effort to solve the problems. The factor analysis method was used to reduce the data. The KMO and Bartlett test was used for the suitability of factor analysis. Similarly, the Cronbach alpha was used to check the internal consistency of the instrument.

Table 2: KMO, Bartlett's Test and Cronbach's Alpha on co-worker's behavior

\begin{tabular}{|l|l|l|}
\hline \multicolumn{2}{|l|}{ Kaiser-Meyer-Olkin Measure of Sampling Adequacy. } & .870 \\
\hline \multirow{3}{*}{ Bartlett's Test of Sphericity } & Approx. Chi-Square & 1695.077 \\
\cline { 2 - 3 } & Df & 66 \\
\cline { 2 - 3 } & Sig. & .000 \\
\hline Cronbach's Alpha & Number of Items \\
\hline
\end{tabular}

Vol. 3. No. I

www.phdcentre.edu.np 
ISSN: 2362-1303 (Paper) | eISSN: 2362-1311(Online)

JOURNAL OF ADVANCED ACADEMIC RESEARCH (JAAR)

Source: survey data 2015

Table 2 summarizes the KMO and Bartlett's test on co-worker's behavior. The KMO (.870) measures as well as Bartlett's test ( $\mathrm{p}<.000)$ showed that factor analysis was suitable for the data analysis. The Cronbach's Alpha value is .651 (65.1\%) of 12 items is reasonable good internal consistency of the instrument.

Table 3 : Total variance explained of co- worker's behavior

\begin{tabular}{|c|c|c|c|c|c|c|c|c|c|}
\hline \multirow[t]{2}{*}{ Component } & \multicolumn{3}{|c|}{ Initial Eigenvalues } & \multicolumn{3}{|c|}{$\begin{array}{ll}\text { Extraction } & \text { Sums } \\
\text { Loadings } & \\
\end{array}$} & \multicolumn{3}{|c|}{$\begin{array}{l}\text { Rotation } \\
\text { Loadings }\end{array}$} \\
\hline & Total & $\%$ of Var. & Cum. \% & Total & $\%$ of Var. & Cum \% & Total & $\%$ of $\mathrm{Var}$ & Cum \% \\
\hline 1 & 3.535 & 29.456 & 29.456 & 3.535 & 29.456 & 29.456 & 3.368 & 28.070 & 28.070 \\
\hline 2 & 1.978 & 16.486 & 45.942 & 1.978 & 16.486 & 45.942 & 2.145 & 17.872 & 45.942 \\
\hline 3 & 1.090 & 9.083 & 55.025 & & & & & & \\
\hline 4 & .855 & 7.129 & 62.154 & & & & & & \\
\hline 5 & .783 & 6.523 & 68.677 & & & & & & \\
\hline 6 & .766 & 6.383 & 75.060 & & & & & & \\
\hline 7 & .662 & 5.517 & 80.577 & & & & & & \\
\hline 8 & .589 & 4.907 & 85.484 & & & & & & \\
\hline 9 & .565 & 4.705 & 90.189 & & & & & & \\
\hline 10 & .483 & 4.024 & 94.213 & & & & & & \\
\hline 11 & .369 & 3.078 & 97.291 & & & & & & \\
\hline 12 & .325 & 2.709 & 100.000 & & & & & & \\
\hline
\end{tabular}

Extraction Method: Principal Component Analysis

The result presented in Table 3 shows three factors extracted of co-worker's behavior $55.025 \%$ of variance was explained in total variance. The third factor could not retain three variables (Ranjan, 2013) which is minimum requirement of factor analysis. Thus, using fixed number factor (confirmatory factor analysis) method, two factors were extracted which satisfied all the requirement of factor analysis. These two factors explain $45.942 \%$ in total variance.

Figure 1 : The scree plot of two factor analysis of co-worker's behavior

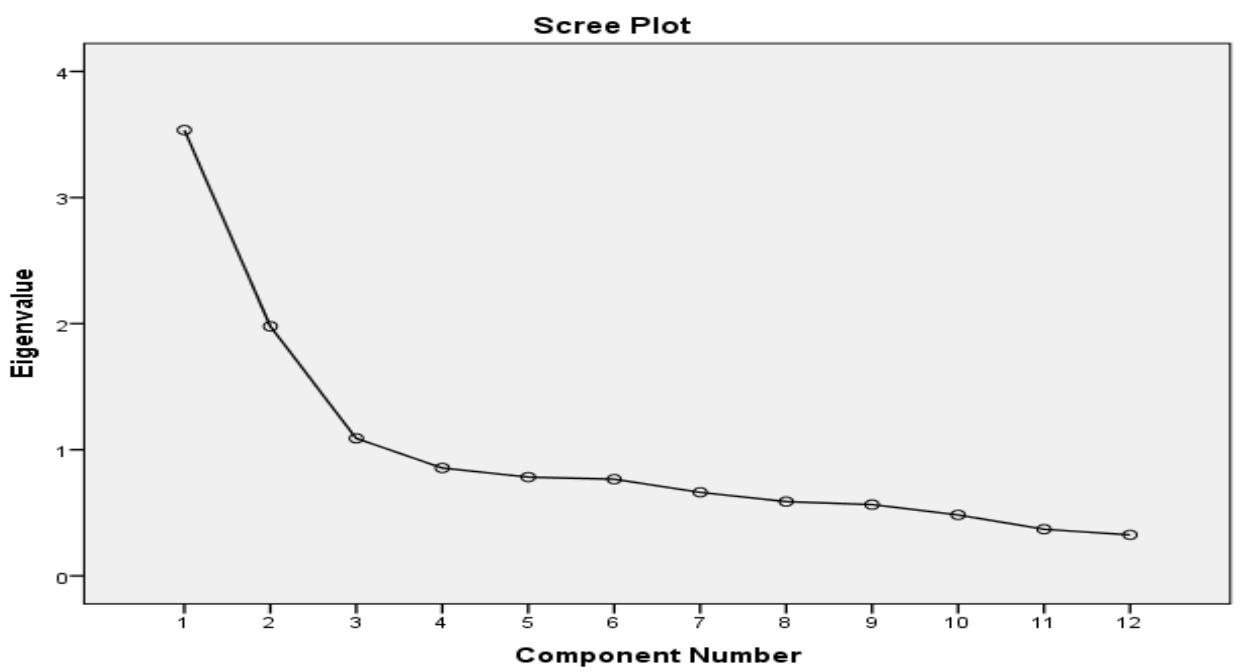

Vol. 3. No. I

www.phdcentre.edu.np 
The exploratory factor analysis extracted three factor having eigenvalue more than 1 . The rotation of Varimax extracted only two variables in third factor. The minimum extracted variable for each factor should be at least three. The scree plot presented in Figure 1, the elbow band is slightly banded at the end of second factor. Based on these two reasons the factor of co-worker's behavior has been limited to two factors using fixed number of factor.

Table 4: Two factor solution of co-worker's behavior on rotated component matrix

\begin{tabular}{|l|l|l|l|}
\hline \multirow{2}{*}{ Variable } & Factor loading & Eigen value \\
\cline { 2 - 4 } & 1 & 2 & Total \\
\hline Co-workers help in solving problem & .676 & -.190 & 0.493573 \\
\hline Co-workers committed to their jobs & .576 & -.009 & 0.331943 \\
\hline Co-workers are friendly & .583 & .124 & 0.354691 \\
\hline Co-workers appreciate on my achievement & .595 & .026 & 0.355002 \\
\hline Provide constructive feedback & .629 & .070 & 0.400253 \\
\hline Share related information & .686 & -.073 & 0.47654 \\
\hline Show jealous expression & -.199 & .840 & 0.744575 \\
\hline Recognize the value & .654 & -.223 & 0.477753 \\
\hline Frequently absent and late & .018 & .840 & 0.705603 \\
\hline Energetic and inspiring & .584 & -.199 & 0.380585 \\
\hline Good blend of skill and talent & .458 & -.046 & 0.211813 \\
\hline Supply low quality of work & .008 & .762 & 0.580691 \\
\hline Eigenvalue & 3.368 & 2.145 & 5.5130 \\
\hline Variances & $28.070 \%$ & $17.872 \%$ & $45.942 \%$ \\
\hline
\end{tabular}

Source: survey data 2015

Two factor solution of co-worker's behavior on rotated component matrix with overlapping value has been presented in Table 4 here. The two components have been extracted and their respective eigenvalue has been given which explains the variance of that variable. The value greater than 0.50 are bolded for clarity.

Table 5: Two factor rotated component matrix of co-worker's behavior

\begin{tabular}{|l|l|l|}
\hline Variables & Factor loadings \\
\cline { 2 - 3 } & 1 & 2 \\
\hline Share related information (32) & .686 & \\
\hline Co-workers help in solving problem (27) & .676 & \\
\hline Recognize the value (34) & .654 & \\
\hline Provide constructive feedback (31) & .629 & \\
\hline Co-workers appreciate on my achievement (30) & .595 & \\
\hline Energetic and inspiring (36) & .584 & \\
\hline Co-workers are friendly (29) & .583 & \\
\hline Co-workers committed to their jobs (28) & .576 & \\
\hline Frequently absent and late (35) & & .840 \\
\hline Show jealous expression (33) & & .840 \\
\hline Supply low quality of work (38) & & .762 \\
\hline So
\end{tabular}

Source: survey data 2015

The value presented in Table 5 in rotated component matrix of co-worker's behavior has been extracted from the factor loading value greater than 0.5 without overlapping. In this point one question was removed that has less than 0.50 factor loading. The component one was named 
team support co-worker's behavior and component two was named lack of co- worker's support behavior subjectively. The team support co-worker's behavior includes eight (8) questions and lack of co- worker's support behavior includes three (3) questions.

Team support co-worker's behavior

Team support co-workers' behavior is an integral part of any organization that plays a vital role in the effective development of any organization. In teamwork the work related stress and pressure is being shared and the responsibility is not gathered on one's shoulder (Rasool \& Lodhi, 2015). Working and supporting in a team not only brings the productivity, but it also expands the individual output. In addition to this, every member of the team puts their interests and needs aside and works towards achieving organizational goals. Thus, effective teamwork is the essential key for the successful business, whereas the lacking and collapses in teamwork damages the position of the organization.

The empirical research shows on the influences of co-workers' relationship, job satisfaction, and organizational commitment through regression analysis and found that job satisfaction is indeed an intervening variable to the relationship between co-workers' relationship and organizational commitment (Lin \& Lin, 2011).

On the contrary, the findings (Butt, Rasil, Khan, \& Iqbal, 2012) revealed that the team work support did not contribute to increases the job commitment of nursing staff working in the hospitals which was inconsistent with this study.

H02: There is no significant relationship between team support co-workers' behavior and attitudinal behavior (job satisfaction, job commitment and job performance) of the faculty members.

Table 6: Analysis of variance (ANOVA) between team support co-worker's and attitudinal behavior

\begin{tabular}{|l|l|l|l|l|l|l|}
\hline \multicolumn{2}{|c|}{} & Sum of Squares & df & Mean Square & F & Sig. \\
\hline \multirow{4}{*}{ Job satisfaction } & Between Groups & 2840.312 & 24 & 118.346 & 4.773 & .000 \\
\cline { 2 - 8 } & Within Groups & 9298.625 & 375 & 24.796 & & \\
\cline { 2 - 8 } & Total & 12138.938 & 399 & & & \\
\hline \multirow{2}{*}{$\begin{array}{l}\text { Job } \\
\text { performance }\end{array}$} & Between Groups & 419.747 & 24 & 17.489 & 3.144 & .000 \\
\cline { 2 - 8 } & Within Groups & 2086.003 & 375 & 5.563 & & \\
\hline \multirow{3}{*}{$\begin{array}{l}\text { Job } \\
\text { commitment }\end{array}$} & Total & 2505.750 & 399 & & & \\
\cline { 2 - 8 } & Between Groups & 1838.418 & 24 & 76.601 & 5.419 & .000 \\
\cline { 2 - 8 } & Wotal & 5301.020 & 375 & 14.136 & & \\
\hline
\end{tabular}

Dependent: Job satisfaction, job performance \& job commitment, Predictor, Team support co-worker's behavior, Source: Survey data 2015

The result presented in Table 6 of ANOVA analysis shows $\mathrm{F}$ - statistics $(\mathrm{F}=4.773)$ and "Sig" $\mathrm{P}$ value $(\mathrm{P}=0.000)$ of job satisfaction, $\mathrm{F}$ - statistics $(\mathrm{F}=3.144)$ and "Sig" $\mathrm{P}$ value $(\mathrm{P}=0.000)$ of job performance, $\mathrm{F}$ - statistics $(\mathrm{F}=5.419)$ and "Sig" $\mathrm{P}$ value $(\mathrm{P}=0.000)$ of job commitment which are lower than 0.05 . Therefore at $5 \%$ of level of significance, the null hypothesis is rejected and alternative hypothesis is accepted. The result shows there is significant difference between the team support co- workers' behavior and job satisfaction, job performance and job commitment of faculty members in educational institutions of Nepal. 


\section{Lack of co-worker's support}

Lack of support refers to not helping each other between the peers or co-workers. In such situation each and every employee works individually and does not share the responsibility and feelings. The working environment lacks of social support. The environment lacks of friends and other people, including family, to turn to in times of need or crisis to give a broader focus and positive self-image that impair quality of life and provides a buffer to adverse life events.

The findings of women occupying most demanding jobs (Madison, 2000) revealed that participants who lacked support from co-workers were more likely to suffer from job dissatisfaction.

H03: There is no significant relationship between lack of co-worker's support and attitudinal behavior (job satisfaction, job commitment and job performance) of the faculty members.

Table 7: Analysis of variance (ANOVA) of lack of co-worker's support and attitudinal behavior

\begin{tabular}{|c|c|c|c|c|c|c|}
\hline & & Sum of Squares & df & Mean Square & $\mathrm{F}$ & Sig. \\
\hline \multirow{3}{*}{ Job satisfaction } & Between Groups & 1992.456 & 12 & 166.038 & 6.333 & .000 \\
\hline & Within Groups & 10146.481 & 387 & 26.218 & & \\
\hline & Total & 12138.938 & 399 & & & \\
\hline \multirow{3}{*}{$\begin{array}{l}\text { Job } \\
\text { Performance }\end{array}$} & Between Groups & 363.722 & 12 & 30.310 & 5.476 & .000 \\
\hline & Within Groups & 2142.028 & 387 & 5.535 & & \\
\hline & Total & 2505.750 & 399 & & & \\
\hline \multirow{3}{*}{$\begin{array}{l}\text { Job } \\
\text { commitment }\end{array}$} & Between Groups & 1063.050 & 12 & 88.587 & 5.642 & .000 \\
\hline & Within Groups & 6076.388 & 387 & 15.701 & & \\
\hline & Total & 7139.437 & 399 & & & \\
\hline
\end{tabular}

Dependent: Job satisfaction, job performance, job commitment Predictor: Lack of co- worker's support, Source: Survey data 2015

The result presented in Table 7 of ANOVA analysis shows $\mathrm{F}$ - statistics $(\mathrm{F}=6.333)$ and "Sig" $\mathrm{P}$ value $(\mathrm{P}=0.000)$ of job satisfaction, $\mathrm{F}$ - statistics $(\mathrm{F}=5.476)$ and "Sig" $\mathrm{P}$ value $(\mathrm{P}=0.000)$ of job performance and $\mathrm{F}$ - statistics $(\mathrm{F}=5.642)$ and "Sig" $\mathrm{P}$ value $(\mathrm{P}=0.000)$ of job commitment which are lower than 0.05 . Therefore at $5 \%$ of level of significance, the null hypothesis is rejected and alternative hypothesis is accepted. There is significant difference between the lack of co-workers' support and job satisfaction, job performance and job commitment of faculty members.

\section{Limitations and future direction}

This study focuses on the co-workers' behavior to determine the attitudinal behavior of the faculty, participants were faculty members of the TU affiliated campuses, Mid -western Development Region was selected as study area, study design was cross sectional and research approach was quantitative in this study thus, the following further direction for researcher has been recommended.

It can be broadened by adding the administrative staff of lower level of educational institutions and other universities of Nepal.

Broadening the study area not only throughout Nepal along with Mid-western Development Region but also other countries can be fruitful for further study.

It can be broadened by changing the research design.

\section{CONCLUSION}

The co-workers' behavior is very important in creating harmonious environment among the workers for the success of any organization. It has been found that the faculties perceived current environment as very weak compared to their expectation towards co-workers' behavior. 
Perception of the faculties towards current and expected working environment regarding coworker's behavior has been found the current environment is very weak compared their expectation towards co-workers behavior. The analysis also found the team support co-workers' behavior has significant positive impact on job satisfaction, job performance and job commitment and whereas, lack of team support co-worker's behavior has the negative impact. Thus, the management should always keep keen interest in improving the harmonious relationship between the co-workers as well as management level employees to increase the efficiency of the organizational as well as employees' performance.

\section{REFERENCES}

Asgharian, R., Md.Yusoff, R., Yaser Mazhari, M., Mardani, A., \& Hazrat Soltan, E. K. (2013, July). Examining the Effect of Workplace Friendships and Job Embeddedness on Turnover Intention (the Case of Mashhad as a Tourist Destination in Iran). International Journal of Business and Management Invention, 2(7), 17-25.

Balu, P. M. (1964). Exchange and Power in Social Life. New York: John wiley.

Betra, D. (2005). Put on a Happy Face : High Morale Can Lift Productivity. National Resturant News, 39(20), pp. 1-8.

Butt, H. S., Rasil, A. B., Khan, F., \& Iqbal, M. J. (2012, June). Impact of Work Physical Environment on Hospial Nurses Commitment. IJER, 3(3), 33-43.

Chiaburu, D. S. (2010). The Social Context of Training: Co-worker, Supervisor, or Organizational Support? Industrial and Commercial Training, 42(1), 53-56.

Chou, R. J., \& Robert, S. A. (2008, June). Workplace Support, Role Overload, and Job Satisfaction of Direct Care Workers in Assisted Living. Journal of Health and Social Behavior, 49(2), 208-222.

Hasan, S. A., \& Subhani, M. I. (2012, January ). Co - Workers Motivational Efforts Pave the Way for Morale and Job Commitement for employee ? European Journal of Economics, Finance and Administrative Sciences. Retrieved from http: // mpra.ub.unimuenchen.de/35684

Homans, G. C. (1958). Social Behavior as Exchange. American Journal of Sociology, 63, 597606.

Irfan, M., \& Lodhi, S. (2015, November). Impact of Teamwork on Employee Motivation: A Case of Banking Sector of Pakistan. The International Journal of Business \& Management, 3(11), 26-33.

Kinnaird, P., Dabbish, L., Kiesler, S., \& Faste, H. (2013). Co - Workers Transparency in a Microtech Marketplace. CSCW, 23-27.

Lin, S.-C., \& Lin, J. S.-J. (2011, April). Impacts of Co-workers' Relationships on Organizational Commitment and Intervening Effects of Job Satisfaction. African Journal of Business Management, 5(8), 3396-3409.

Madison, D. (2000). Can Your Job Make You Sick ? in Job Satisfaction Amonest Employees at a Public Health Instution Cape by Nazaam .

Morris, R. J. (2009). Employee Work Motivation and Discretionary Work Efforts.

Nyathi, M., \& Jooste, K. (2008). Working Conditions That Contribute to Absenteeism Among Nurses in a Provincial Hospital in The Limpopo Province. Curtains, 31(1), 28-37.

Ranjan, R. (2013). Employee Turnover and Retention Strategies in Non Profit Organizations in India: An Empirical Study. Unpublished PhD Thesis. 
Rasool, M., \& Lodhi, S. (2015). Impact of Teamwork on Employee Coordination: A Case of Pakistan. The International Journal of Business \& Management, 3(11), 20-25.

Rizwan, M., Khan, W. M., Tariq, H. M., Ghaffar, A., Anjum, M. Z., \& Bajwa, E. U. (2012). Empirical Study of Employee Job Satisfaction. IOSR Journal of Business and Management, 29-35.

Wainaina, J. K., Kipchumba, S., \& Kombo, H. (2014, February ). A Study on Effect of CoWorkers and Student - Teacher Relationship on Teachers organizzational Commitment in Publish Secondary School : A Case of Nakuru North District Kenya. International Journal of Education and Research, 2(2), 1-16. 